\title{
OCULAR MANIFESTATIONS OF PARENTERAL ADMINISTRATION OF SCOPOLAMINE (HYOSCINE)*
}

BY

\author{
KRISHNA SWAMI MEHRA, P. CHANDRA, AND B. B. KHARE \\ College of Medical Sciences, Benares, India
}

CoNfLicting reports of the effect on intra-ocular pressure and pupil size of intramuscular atropine and scopolamine have appeared in the literature. According to Leopold and Comroe (1948) seven out of eight patients showed $1 \mathrm{~mm}$. mydriasis with intramuscular scopolamine. Edmunds and Gunn (1941) found that neither drug had any adverse effect in the conventional pre-operative dosage. Hale (1954) found that the effect of scopolamine was greater, and Adriani (1960) found that both drugs caused mydriasis, atropine being the more effective. Mehra and Chandra (1965) found that in a series of 100 patients who received intramuscular atropine, $0 \cdot 1 \mathrm{mg}$. per $14 \mathrm{lb}$. body-weight, thirteen showed mydriasis up to $2 \mathrm{~mm}$. and nine showed a rise in ocular tension up to $3 \mathrm{~mm} . \mathrm{Hg}$ (Schiötz). The present study concerns the effect of intramuscular scopolamine, and was prompted by the need to find a safe premedication for glaucomatous patients requiring drainage operations under general anaesthesia.

\section{Material}

The investigation was carried out in 100 patients with normal pupil size and intra-ocular pressure and ten patients with glaucoma. They were of both sexes and their ages ranged from 10 to 50 years.

\section{Method}

The patients were examined by artificial light. They were asked to look at a distant object while the pupil size was measured. The ocular tension was measured with a Schiötz tonometer with three weights.

The pupil size and ocular tension were noted before and 15, 30, 45, and 60 min. after the intramuscular administration of hyoscine hydrobromide $0.06 \mathrm{mg}$. per $14 \mathrm{lb}$. body-weight.

\section{Results}

In the 100 normal subjects, the pupil size increased in 9 per cent. and the intraocular pressure in only 5 per cent. In the ten glaucomatous patients no change occurred. These results are set out in the Table. 
TABLE

Results in 100 Normal Subjects and 10 Patients with Glaucoma

\begin{tabular}{l|c|c|c|c|c|c}
\hline \multirow{2}{*}{ Series } & \multirow{2}{*}{ No. of Patients } & \multirow{2}{*}{ Sex } & \multicolumn{2}{|c|}{$\begin{array}{c}\text { Mydriasis } \\
(\mathrm{mm} .)\end{array}$} & \multicolumn{2}{c}{$\begin{array}{c}\text { Rise in } \\
\text { Intra-ocular Pressure } \\
\text { (mm. Hg) }\end{array}$} \\
\cline { 4 - 7 } & & & None & $0-2$ & None & $0-2$ \\
\hline \multirow{3}{*}{ Normal } & 48 & Male & 43 & 5 & 45 & 3 \\
& 52 & Female & 48 & 4 & 50 & 2 \\
\hline \multirow{2}{*}{ With Glaucoma } & 100 & Total & 91 & 9 & 95 & 5 \\
\cline { 2 - 7 } & 5 & Male & 5 & 0 & 5 & 0 \\
& 5 & Female & 5 & 0 & 5 & 0 \\
\hline
\end{tabular}

\section{Conclusion}

It appears that scopolamine affords a safe method of premedication before general anaesthesia in cases of glaucoma. Mydriasis and increased ocular tension occurred in a very small percentage of normal subjects.

\section{REFERENCES}

Adriani, J. (1960). "The Pharmacology of Anaesthetic Drugs", 4th ed., p. 136. Charles C. Thomas, Springfield, Ill.

Edmunds, C. W., and GunN, J. A. (1941). “Cushny's Pharmacology and Therapeutics”, 12th ed., p. 503. Churchill, London.

HALE, D. E. (1954). "Anesthesiology". Davis, Philadelphia.

LeOPOLD, I. H., and Comroe, J. H. (1948). Arch. Ophthal. (Chicago), 40, 285.

MeHra, K. S., and ChandRa, P. (1965). Brit. J. Anaesth., 37, 133. 